\title{
Chemical defenses of the Caribbean sponges Agelas wiedenmayeri and Agelas conifera
}

\author{
Michael Assmann ${ }^{1}$, Ellen Lichte ${ }^{1}$, Joseph R. Pawlik ${ }^{2}$, Matthias Köck ${ }^{1, *}$ \\ ${ }^{1}$ Institut für Organische Chemie, Johann Wolfgang Goethe-Universität, Marie-Curie-Straße 11, 60439 Frankfurt am Main, \\ Germany \\ ${ }^{2}$ Biological Sciences and Center for Marine Science, University of North Carolina at Wilmington, Wilmington, \\ North Carolina 28403-3297, USA
}

\begin{abstract}
Previous studies have determined that Caribbean reef sponges of the genus Agelas are chemically defended from fish predation by brominated pyrrole alkaloids, and that the compounds responsible for this defense have been elucidated for 1 species, A. clathrodes. In this study, we expand our understanding of chemical defense in this common sponge genus to include the characterization of defensive metabolites in the tissues of $A$. wiedenmayeri and A. conifera. Bioassay-directed isolation of defensive metabolites was undertaken using fish feeding assays carried out in laboratory aquaria and in the field. A. wiedenmayeri contained the same 2 major metabolites as A. clathrodes, 4,5-dibromopyrrole-2-carboxylic acid (1), and oroidin (2), in addition to a small amount of bromoageliferin (7). The 2 major metabolites were present at higher concentrations in samples of $A$. wiedenmayeri than in $A$. clathrodes, and their relative concentrations were reversed, with $A$. wiedenmayeri on average containing more 4,5-dibromopyrrole-2-carboxylic acid (1) $\left(2.0 \mathrm{mg} \mathrm{ml}^{-1}\right)$ than oroidin (2) $\left(0.8 \mathrm{mg} \mathrm{ml}^{-1}\right)$. A. conifera contained a mixture of dimeric bromopyrrole alkaloids dominated by sceptrin (3), with $<10 \%$ each of dibromosceptrin (5), bromoageliferin (7), dibromoageliferin (8), ageliferin (6), and bromosceptrin (4). Mean concentration of sceptrin (3) in sponge tissue was $5.3 \mathrm{mg} \mathrm{ml}^{-1}$; this compound deterred feeding of reef fish in aquarium assays at $1.0 \mathrm{mg} \mathrm{ml}^{-1}$, the lowest concentration assayed. Sceptrin (3) concentrations were higher in sponges collected in the southern Bahama Islands than in those collected in the middle Bahamas, but the reasons for this variation remain unclear. The structure-activity relationship of the pyrrole group was investigated by assaying derivatives of the active metabolites. Feeding deterrent activity of the molecule was enhanced by the addition of bromine to the pyrrole group, but not affected by exchange of the heteroatom from $\mathrm{N}$ to $\mathrm{O}$ or $\mathrm{S}$. Combining an understanding of the structure-activity relationship of Agelas metabolites with an understanding of the variation in these metabolites across the genus may provide insight into the evolution of defensive chemistry in this highly successful taxa of pan-tropical sponges.
\end{abstract}

KEY WORDS: Chemical defense - Sponge · Agelas $\cdot$ Caribbean $\cdot$ Alkaloids $\cdot$ Structure-activity relationship

Resale or republication not permitted without written consent of the publisher

\section{INTRODUCTION}

Sponges of the genus Agelas (Family Agelasidae) are important components of Caribbean coral-reef communities because they are abundant in a variety of habi-

${ }^{*}$ Corresponding author. Present address: Alfred-WegenerInstitut für Polar- und Meeresforschung, Am Handelshafen 12, 27570 Bremerhaven, Germany.

E-mail: mkoeck@awi-bremerhaven.de tats from shallow back-reef to deep-reef slope. Chemically, Agelas spp. are distinct because they contain primarily brominated pyrrole alkaloids as secondary metabolites, although other classes of compounds have been isolated from this genus (Braekman et al. 1992). The ecological roles of these compounds have only recently been examined. The antipredatory effects of crude organic extracts of 6 species of Caribbean Agelas sponges (A. clathrodes, A. conifera, A. dispar, A. inaequalis, A. sceptrum, A. wiedenmayeri) were sur- 
veyed using a common generalist fish, the bluehead wrasse Thalassoma bifasciatum, as an assay organism (Pawlik et al. 1995). For A. clathrodes, 2 previously described major metabolites, 4,5-dibromopyrrole-2-carboxylic acid (1), and oroidin (2; Fig. 1), were successfully identified as the deterrent metabolites (Chanas et al. 1996). Besides these 2 brominated alkaloids, a series<smiles>O=C(O)c1cc(Br)c(Br)[nH]1</smiles><smiles>Nc1ncc(CCNC(=O)c2cc(Br)c(Br)[nH]2)[nH]1</smiles><smiles>[X]c1c[nH]c(C(=O)NCC(CNC(=O)c2cc([X])c([Y])[nH]2)C(c2cnc(N)[nH]2)c2cnc(N)[nH]2)c1</smiles>
3-5

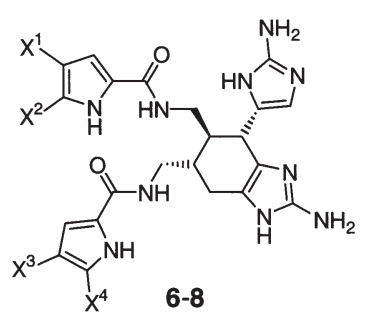

3: $\mathrm{X}^{1}=\mathrm{Br}, \mathrm{X}^{2}=\mathrm{H}, \mathrm{X}^{3}=\mathrm{Br}, \mathrm{X}^{4}=\mathrm{H}$ 4: $X^{1}-X^{3}=B r, X^{4}=H$ 5: $X^{1}-X^{4}=B r$

6: $\mathrm{X}^{1}=\mathrm{Br}, \mathrm{X}^{2}=\mathrm{H}, \mathrm{X}^{3}=\mathrm{Br}, \mathrm{X}^{4}=\mathrm{H}$ $7: X^{1}-X^{3}=B r, X^{4}=H$

8: $X^{1}-X^{4}=B r$<smiles>O=C(O)c1ccc[nH]1</smiles><smiles>O=C(O)c1cc(Br)c[nH]1</smiles><smiles>COC(=O)c1ccc[nH]1</smiles><smiles>NC(=O)c1ccc[nH]1</smiles><smiles>O=C(O)c1cccs1</smiles><smiles>O=C(O)c1ccc(Br)s1</smiles><smiles>NC(=O)c1cccs1</smiles><smiles>O=C(O)C1CCCN1</smiles><smiles>O=C(O)C1CCCN1</smiles>

20

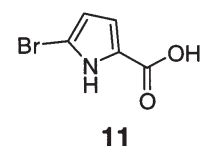<smiles>O=Cc1ccc[nH]1</smiles>

14<smiles>O=C(O)c1ccco1</smiles>

19

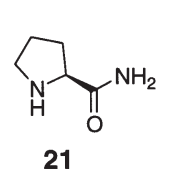

21 of dimeric bromopyrrole alkaloids, the sceptrins and ageliferins, have been isolated from $A$. conifera, A. sceptrum and A. sp. (Walker et al. 1981, Kobayashi et al. 1990, Keifer et al. 1991). Although it was surmised that the dimeric brominated alkaloids found in other species of Agelas from the Caribbean deterred feeding (Pawlik et al. 1995, Chanas et al. 1996), purified compounds were never tested.

We identified the brominated alkaloid metabolites in the feeding deterrent fraction of crude extracts of Agelas wiedenmayeri and A. conifera. Inter- and intraspecific variation in the concentrations of these metabolites in 5 specimens of $A$. wiedenmayeri and in 24 specimens of $A$. conifera were quantified by HPLC. Purified samples of dimeric bromopyrrole alkaloids isolated from $A$. conifera were tested at a range of concentrations in aquarium and field assays. Building on a recent study of the structure-activity relationship of synthetic oroidin-related alkaloids as feeding deterrents that focused on the 2-amino-imidazole-moiety (Lindel et al. 2000), the present study further investigated the importance of modification of the pyrrole part in altering compound activity.

\section{MATERIALS AND METHODS}

Sponge collection and identification. This study was performed over the course of 3 research expeditions: one at the National Undersea Research Center in Key Largo, Florida, USA, in May 1998, one on board the RV 'Edwin Link' in the Bahama Islands in September and October 1998, and one on-board the RV 'Seward Johnson' in the Bahama Islands in July and August 1999. Collection sites in the Bahamas are shown in Fig. 2.

Agelas wiedenmayeri (Alcolado) and A. conifera (Schmidt) were collected by SCUBA diving at all sites. Portions of sponges were collected by cutting tissue with a sharp knife, leaving the remaining sponge intact for re-growth. For each species, replicate collections were taken from distant sites $(>10 \mathrm{~km})$ to avoid collecting asexually produced clones. Tissue samples were immediately frozen and stored at $-20^{\circ} \mathrm{C}$ until used for extractions. Sponges were identified on the basis of spicule and tissue preparations at the Zoölogisch Museum, Universiteit van Amsterdam, The Netherlands (Assmann \& van Soest unpubl. results).

Isolation of deterrent metabolites. A freeze-dried sample of Agelas conifera ( $473 \mathrm{~g} \cong 2400 \mathrm{ml}$ sponge tissue), collected in May 1998 at Elbow Reef, Key Largo, Florida, USA, was extracted 3 times in methanol, twice in 1:1 methanol:dichloromethane, and once in dichloromethane. The organic extracts were combined and evaporated to dryness. The obtained crude extract was

partitioned between $n$-hexane and methanol.
Fig. 1. Secondary metabolites isolated from Agelas wiedenmayer $(\mathbf{1}, \mathbf{2}, \mathbf{7})$ and $A$. conifera $(\mathbf{3}-\mathbf{5}, \mathbf{6 - 8})$ : 4,5-dibromopyrrole-2-carboxylic (5), ageliferin (6), bromoageliferin (7), dibromoageliferin (8). The remaining compounds were used to test structure-activity relationships, and were synthesized $(\mathbf{1 0 - 1 3}, \mathbf{1 8})$, or purchased $(\mathbf{9}, \mathbf{1 4}-\mathbf{1 7}$, 19-22): pyrrole-2-carboxylic acid (9), 4-bromopyrrole-2-carboxylic acid (10), 5-bromopyrrole-2-carboxylic acid (11), pyrrole-2-carboxylic acid methyl ester (12), pyrrole-2-carboxamide (13), pyrrole2-carboxaldehyde (14), 2-furancarboxylic acid (15), thiophene-2carboxylic acid (16), 5-bromothiophene-2-carboxylic acid (17), thiophene-2-carboxamide (18), D-proline (19), L-proline (20), Lprolinamide (21), L-proline methyl ester hydrochloride (22) 
The methanol extract (18.9 g) was partitioned again between $n$-butanol and water. The $n$-butanol phase was concentrated and the residue (10.7 g) was purified by gel chromatography (Sephadex LH-20, methanol). A part of the fraction containing sceptrins and ageliferins $(2.03 \mathrm{~g})$ was further purified by preparative RP-HPLC to yield sufficient amounts of sceptrin (3), bromosceptrin (4), dibromosceptrin (5), ageliferin (6), bromoageliferin (7), and dibromoageliferin (8) for subsequent feeding assays. Isolation of brominated alkaloids from a specimen of Agelas wiedenmayeri, which had been collected in May 1998 at North Dry Rocks, Key Largo, was performed using a previously described procedure (Assmann et al. 1999). The isolated bromopyrrole alkaloids of both $A$. conifera and $A$. wiedenmayeri were identified by comparison of mass spectrometry and NMR data with those previously reported (Forenza et al. 1971, Garcia et al. 1973, Walker et al. 1981, Kobayashi et al. 1990, Keifer et al. 1991) as well as on the basis of 2D NMR data (COSY, HSQC, HMBC).

Extraction of crude extracts for quantification of metabolites. Sponge volume was determined by displacement of water or solvent with frozen material. Frozen tissue (Agelas conifera), or freeze-dried tissue (approximately $1.9 \mathrm{~g}$ freeze-dried material corresponds to $10 \mathrm{ml}$ frozen sponge tissue of $A$. wiedenmayeri), from individual sponge specimens was chopped into small pieces and added to $40 \mathrm{ml}$ of a 1:1 mixture of dichloromethane:methanol in a graduated centrifuge tube to a final volume of $50 \mathrm{ml}$. Capped tubes were inverted, agitated repeatedly, and shaken at room temperature during $24 \mathrm{~h}$ extraction time. After extraction, both phases were filtered and the solvent mixture was evaporated to dryness on a rotary evaporator using low heat $\left(40^{\circ} \mathrm{C}\right)$. The remaining tissue was ex-tracted by shaking a second time with methanol for $24 \mathrm{~h}$ at room temperature, and the resulting extract was filtered. The organic extracts (methanol extract and dichloromethane:methanol extract) were combined and evaporated. The obtained residue was dissolved in a mixture of $15 \mathrm{ml}$ methanol and $15 \mathrm{ml}$ methanol:dichloromethane and transferred into $50 \mathrm{ml}$ graduated centrifuge tubes. From this mixture a volume of $1.5 \mathrm{ml}$ was kept for subsequent HPLC quantification. The remaining solvent $(28.5 \mathrm{ml})$ was removed by Speed-Vac vacuum concentration and finally dried under vacuum. Three replicate crude extracts of each specimen were prepared in the same way and quantified by HPLC.

Quantification of secondary metabolites by HPLC. From the $1.5 \mathrm{ml}$ volume of each crude extract saved for HPLC quantification, $200 \mu \mathrm{l}$ were transferred to a vial and the solvent removed by Speed-Vac vacuum concentration. The obtained residue was dissolved in $500 \mu$ l acetonitrile:water 1:1 + 0.5\% trifluoroacetic acid and $10 \mu \mathrm{l}$ injected by auto-sampling into a HPLC

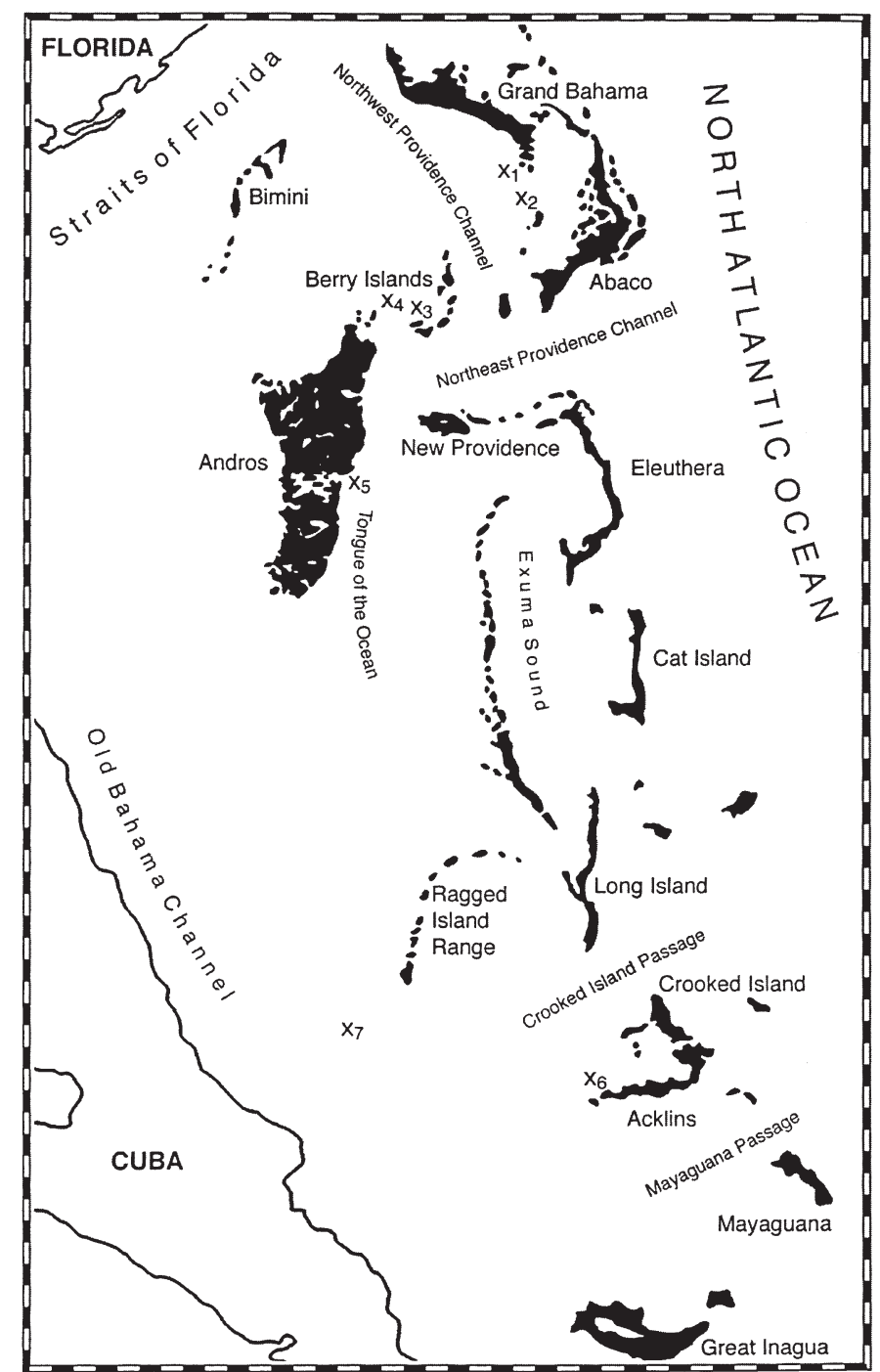

Fig. 2. Map of the Bahama Islands indicating collection sites of Agelas conifera. $\mathrm{x}_{1}$ : Sweetings Cay; $\mathrm{x}_{2}$ : Black Rock; $\mathrm{x}_{3}$ : Chub Cay; $\mathrm{x}_{4}$ : $33 \mathrm{~km}$ west of Chub Cay; $\mathrm{x}_{5}$ : Behring Point; $\mathrm{x}_{6}$ : Acklins; $\mathrm{x}_{7}$ : Cay Santo Domingo

system equipped with a photodiode-array detector (JASCO). Routine UV detection was at $280 \mathrm{~nm}$. The separation column (analytical: $4.6 \times 250 \mathrm{~mm}, 5 \mu \mathrm{m}$ ) was pre-filled with Kromasil RP-18 (Knauer GmbH) (gradient: 20 to $60 \%$ acetonitrile:water $+0.1 \%$ trifluoroacetic acid in $40 \mathrm{~min}$; flow rate: $1 \mathrm{ml} \mathrm{min}^{-1}$ ). Each quantitative analysis based on peak area calibration was achieved using purified sceptrin (3) (Agelas conifera) or oroidin (2) and 4,5-dibromopyrrole-2-carboxylic acid (1) (A. wiedenmayeri) as an external standard.

Synthesis of pyrrole-2-carboxylic acid derivatives. For studying the structure-activity relationship of the pyrrole part of bromopyrrole alkaloids, brominated pyrrole-2-carboxylic acid derivatives were either purchased commercially $(\mathbf{9}, \mathbf{1 4}-\mathbf{1 7}, \mathbf{1 9 - 2 2})$ or synthesized 
(10-13, 18) following procedures previously described by Bailey et al. (1971) and Anderson \& Lee (1965). Structures of the compounds were determined by mass spectrometry and NMR spectroscopy.

Aquarium feeding assays. Purified natural or synthetic compounds were dissolved in a minimal volume of methanol and mixed with $1 \mathrm{ml}$ of alginate-based food matrix (Pawlik et al. 1987, 1995) until all organic and water-soluble components were distributed uniformly throughout the paste. The alginate food matrix was then dispensed with a $1 \mathrm{ml}$ syringe into a $0.25 \mathrm{M}$ calcium chloride solution forming a strand that was allowed to harden for $2 \mathrm{~min}$. The hardened strand was rinsed with filtered seawater and cut into $3 \mathrm{~mm}$ pellets with a scalpel. Control pellets were prepared identically but without the addition of natural or synthetic compounds. Feeding assays were performed with fish (1 terminal phase and 2 females in each of 10 compartments) in aquaria on board the RV 'Seward Johnson' or at the University of North Carolina at Wilmington using a common predatory reef fish, the bluehead wrasse Thalassoma bifasciatum. Rationale for the choice of this assay fish, and an explanation of the methods for scoring the assay and the statistical analysis, is well described in Pawlik et al. (1995). Each replicate assay was performed on a separate group of fish.

Field feeding assay. For field assays, a purified mixture containing sceptrins (3-5) and ageliferins (6-8) of Agelas conifera from a $60 \mathrm{ml}$ volume sponge tissue was dissolved in a minimal volume of methanol and combined with $60 \mathrm{ml}$ of preheated carrageenan-based food (Chanas \& Pawlik 1995). Food dyes were added to both treated and control foods to make them the same color. The mixture was then poured into molds crossed by lengths of cotton string and allowed to harden. After hardening, 20 string-embedded strips were cut from the molds. Control strips were prepared identically, but without the addition of bromopyrrole alkaloids. Field assays were conducted on shallow water reefs $(<15 \mathrm{~m})$ off the Bahamas (South Bimini, North Turtle Rock) using previously described methods regarding deployment, retrieval and statistical analyses (Chanas \& Pawlik 1995).

\section{RESULTS}

It had previously been established that the feeding deterrent activity of crude organic extracts of Caribbean Agelas spp. was localized in the brominated pyrrole alkaloid fraction of the extract (Pawlik et al. 1995, Chanas et al. 1996). For A. wiedenmayeri, the alkaloid fraction contained 4,5-dibromopyrrole-2-carboxylic acid (1), oroidin (2), and bromoageliferin (7), in the approximate mixture of 63,28 and $9 \%$, respectively. For $A$. conifera, the fraction contained dimeric alkaloids in the approximate proportion of $68 \%$ sceptrin (3), $9 \%$ dibromosceptrin (5), $8 \%$ bromoageliferin (7), $6 \%$ dibromoageliferin (8), $5 \%$ ageliferin (6), and $4 \%$ bromosceptrin (4).

The major metabolites in the alkaloid mixtures for both sponges were quantified by HPLC for 5 specimens of Agelas wiedenmayeri and for 24 specimens of $A$. conifera (Tables $1 \& 2$ ). Mean concentrations of 4,5-dibromopyrrole-2-carboxylic acid (1) and oroidin (2) in the 2 samples of $A$. wiedenmayeri were 2.00 and $0.82 \mathrm{mg}$ $\mathrm{ml}^{-1}$, respectively. Concentrations of oroidin in the 2 sponge samples from Cay Sal Bank (Bahamas) were much higher than those from Key Largo, Florida, but the low sample number precluded statistical analysis.

The mean concentration of sceptrin (3) in all samples of $A$. conifera was $5.3 \mathrm{mg} \mathrm{ml}^{-1}$ (Table 2). When the data were subdivided into 3 sets of samples collected in the northern Bahamas, middle Bahamas, and southern Bahamas, a significant difference in mean sceptrin content was found between the middle and southern collections, but not between the northern and southern collections or the northern and middle collections (ANOVA, $F_{2,21}=4.03$, p < 0.05; Tukey multiple comparison, $\alpha=0.05$; Zar 1999).

The 4 major bromopyrrole alkaloids present in the feeding deterrent fraction from the crude organic ex-

Table 1. Concentration of 4,5-dibromopyrrole-2 carboxylic acid (1) and oroidin (2) in samples of Agelas wiedenmayeri from the Florida Keys ${ }^{*}$ and the Bahamas ${ }^{* *}$

\begin{tabular}{|c|c|c|c|c|c|}
\hline Sample & Location & $\begin{array}{c}\text { Date } \\
\text { (d.mo.yr) }\end{array}$ & $\begin{array}{l}\text { Depth } \\
\text { (m) }\end{array}$ & $\begin{array}{c}\text { 4,5-dibromo-pyrrole-2- } \\
\text { carboxylic acid }\left(\mathrm{mg} \mathrm{ml}^{-1}\right) \\
\text { mean } \pm \mathrm{SD}\end{array}$ & $\begin{array}{c}\text { Oroidin } \\
\left(\mathrm{mg} \mathrm{m}^{-1}\right) \\
\text { mean } \pm \mathrm{SD}\end{array}$ \\
\hline MAWIE1 & North Dry Rocks* & 26.05 .1998 & 9 & $2.51 \pm 0.14$ & $0.10 \pm 0.03$ \\
\hline MAWIE2 & Conch $^{*}$ & 29.05 .1998 & 16 & $1.65 \pm 0.16$ & $0.72 \pm 0.01$ \\
\hline MAWIE3 & North Dry Rocks* & 23.05 .1998 & 6 & $2.42 \pm 0.15$ & $0.20 \pm 0.06$ \\
\hline MAB146 & Cay Sal Bank** & 08.08 .1999 & 6 & $1.83 \pm 0.20$ & $1.86 \pm 0.36$ \\
\hline MAB147 & Cay Sal Bank** & 08.08 .1999 & 6 & $1.61 \pm 0.76$ & $1.23 \pm 0.95$ \\
\hline Mean & & & & $2.00 \pm 0.43$ & $0.82 \pm 0.75$ \\
\hline
\end{tabular}


Table 2. Concentration of sceptrin (3) in samples of Agelas conifera from the Bahamas

\begin{tabular}{|c|c|c|c|c|}
\hline Sample & Location & $\begin{array}{c}\text { Date } \\
\text { (d.mo.yr) }\end{array}$ & $\begin{array}{l}\text { Depth } \\
\text { (m) }\end{array}$ & $\begin{array}{c}\text { Sceptrin }\left(\mathrm{mg} \mathrm{ml}^{-1}\right) \\
\text { mean } \pm \mathrm{SD}\end{array}$ \\
\hline \multicolumn{5}{|c|}{ Northern Bahamas } \\
\hline MAB23 & Black Rock & 18.09 .1998 & 5 & $7.0 \pm 4.6$ \\
\hline MAB03 & Sweetings Cay & 16.09 .1998 & 18 & $4.1 \pm 2.0$ \\
\hline MAB76 & Sweetings Cay & 29.07 .1999 & 18 & $3.7 \pm 3.4$ \\
\hline MAB14 & Sweetings Cay & 17.09 .1998 & 19 & $5.8 \pm 0.2$ \\
\hline Mean & & & & $5.15 \pm 1.53$ \\
\hline \multicolumn{5}{|c|}{ Middle Bahamas } \\
\hline MAB35 & Chub Cay & 19.09 .1998 & 4 & $3.3 \pm 1.7$ \\
\hline MAB38 & Chub Cay & 19.09 .1998 & 11 & $5.2 \pm 0.4$ \\
\hline MAB85 & Chub Cay & 30.07 .1999 & 16 & $3.3 \pm 0.3$ \\
\hline MAB87 & Chub Cay & 30.07 .1999 & 17 & $7.7 \pm 1.4$ \\
\hline MAB32 & Chub Cay & 19.09 .1998 & 18 & $3.3 \pm 1.6$ \\
\hline MAB86 & Chub Cay & 30.07 .1999 & 18 & $5.1 \pm 0.2$ \\
\hline MAB29 & Chub Cay & 19.09.1998 & 20 & $2.9 \pm 1.4$ \\
\hline MAB84 & Chub Cay & 30.07 .1999 & 20 & $3.5 \pm 0.9$ \\
\hline MAB26 & Chub Cay & 19.09 .1998 & 21 & $3.1 \pm 3.6$ \\
\hline MAB28 & Chub Cay & 19.09 .1998 & 21 & $5.2 \pm 1.4$ \\
\hline MAB25 & Chub Cay & 19.09 .1998 & 22 & $4.0 \pm 0.9$ \\
\hline MAB93 & Chub Cay & 30.07 .1999 & 24 & $8.9 \pm 1.8$ \\
\hline MAB43 & $33 \mathrm{~km}$ west of $\mathrm{CC}$ & 21.09 .1998 & 18 & $3.3 \pm 1.0$ \\
\hline MAB100 & Behring Point & 31.07 .1999 & 18 & $6.6 \pm 2.1$ \\
\hline MAB102 & Behring Point & 31.07 .1999 & 19 & $5.4 \pm 0.2$ \\
\hline MAB101 & Behring Point & 31.07 .1999 & 22 & $4.8 \pm 0.3$ \\
\hline Mean & & & & $4.73 \pm 1.77$ \\
\hline \multicolumn{5}{|c|}{ Southern Bahamas } \\
\hline MAB144 & Cay Santo Domingo & 07.08 .1999 & 20 & $8.7 \pm 0.7$ \\
\hline MAB130 & Acklins Island & 05.08 .1999 & 21 & $4.3 \pm 0.5$ \\
\hline MAB129 & Acklins Island & 05.08 .1999 & 23 & $11.0 \pm 0.1$ \\
\hline MAB131 & Acklins Island & 05.08 .1999 & 30 & $7.1 \pm 1.1$ \\
\hline Mean & & & & $7.78 \pm 2.82$ \\
\hline Grand me & & & & $5.30 \pm 2.16$ \\
\hline
\end{tabular}

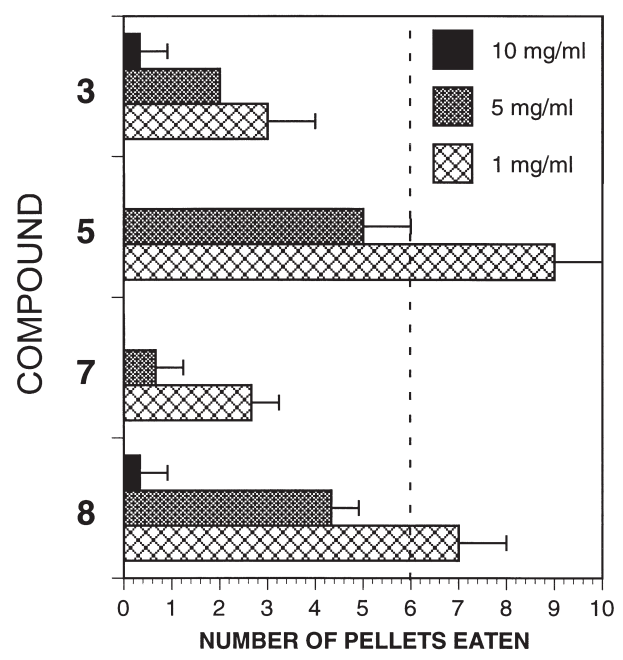

Fig. 3. Aquarium assay results of feeding by Thalassoma bifasciatum on pellets treated with sceptrin (3), dibromosceptrin (5), bromoageliferin (7), and dibromoageliferin (8) isolated from Agelas conifera at concentrations of 1,5 , and $10 \mathrm{mg} \mathrm{ml}^{-1}$. All control pellets were eaten in all assays. Three replicate assays were performed at each concentration. One SD above the mean number of food pellets eaten is indicated. For any individual assay, a treatment was considered deterrent if the number of pellets eaten was less than or equal to 6 ( $p<$ 0.043, Fisher exact test, 1-tailed) as indicated by the dashed line tract of Agelas conifera were isolated, purified, and subjected to feeding assays at concentrations of 1,5 and $10 \mathrm{mg} \mathrm{ml}^{-1}$ (Fig. 3). Sceptrin (3) and bromoageliferin (8) were deterrent at all 3 concentrations, while dibromosceptrin (5) and dibromoageliferin (8) deterred feeding in aquarium assays at 5 and $10 \mathrm{mg} \mathrm{ml}^{-1}$, but not at $1 \mathrm{mg} \mathrm{ml}^{-1}$ (Fig. 3). Only the major metabolite sceptrin (3) deterred fish feeding within the range of natural concentrations (Table 2). Sceptrin (3) was subsequently tested at lower concentrations and was not significantly deterrent: 8 of 10 pellets eaten at $0.8 \mathrm{mg}$ $\mathrm{ml}^{-1}$ and 10 of 10 pellets eaten at $0.5 \mathrm{mg} \mathrm{ml}^{-1}$.

A reconstituted mixture of purified dimeric bromopyrrole alkaloids from Agelas conifera deterred feeding of a natural assemblage of reef fish in a field assay (Fig. 4). This assay was performed at a total natural compound concentration of $1.5 \mathrm{mg} \mathrm{ml}^{-1}$, with the following compound proportions approximating those found in sponge tissue by HPLC quantification: sceptrin (3) (1.02 mg ml-1), dibromosceptrin (8) $(0.13 \mathrm{mg}$ $\left.\mathrm{ml}^{-1}\right)$, bromoageliferin (7) $\left(0.12 \mathrm{mg} \mathrm{ml}^{-1}\right)$, dibromo-

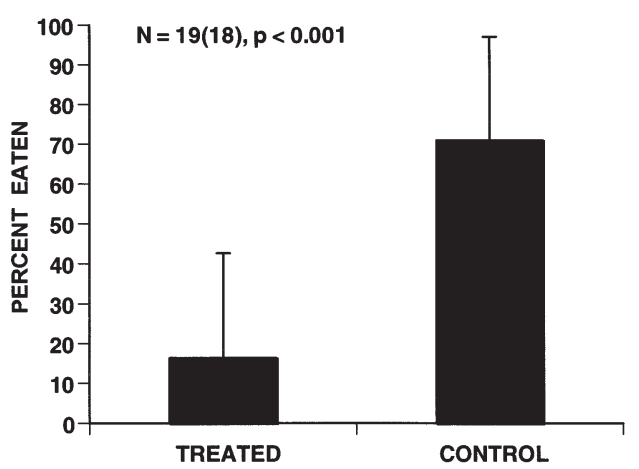

Fig. 4. Consumption by reef fishes of food strips treated with a purified mixture isolated from Agelas conifera containing only dimeric bromopyrrole alkaloids at natural concentrations and control food strips in a field assay. The tested mixture contained $68.3 \%$ sceptrin (3), $8.6 \%$ dibromosceptrin (5), $7.7 \%$ bromoageliferin (7), $6.1 \%$ dibromoageliferin (8), $4.7 \%$ ageliferin (6), and $3.5 \%$ bromosceptrin (4). Mean +1 SD indicated. p-value computed using Wilcoxon paired-sample test (2tailed); $\mathrm{N}=$ number of ropes retrieved out of 20 ropes deployed (number of ropes used in statistical analysis) 


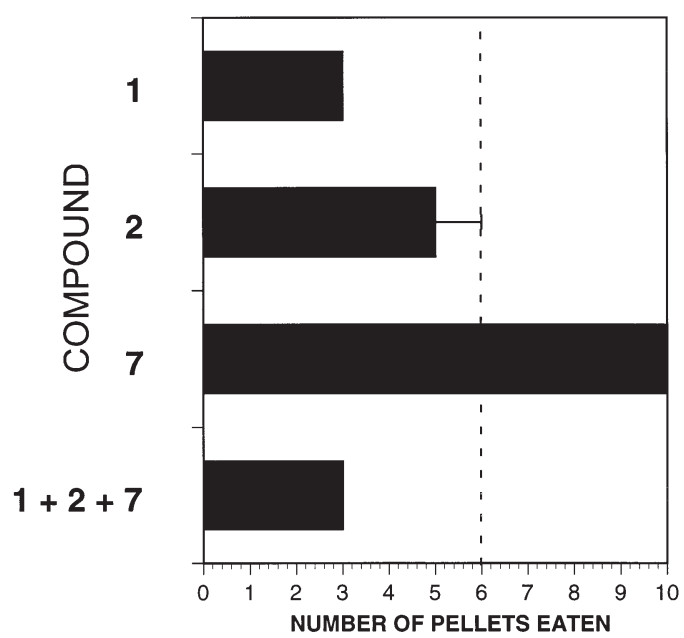

Fig. 5. Aquarium assay results of feeding by Thalassoma bifasciatum on pellets treated with purified bromopyrrole alkaloids isolated from Agelas wiedenmayeri at natural concentrations: 4,5-dibromopyrrole-2-carboxylic acid (1) at $1.6 \mathrm{mg}$ $\mathrm{ml}^{-1}$, oroidin (2) at $0.7 \mathrm{mg} \mathrm{ml}^{-1}$, and bromoageliferin (7) at $0.24 \mathrm{mg} \mathrm{ml}^{-1}$. All control pellets were eaten in all assays. Three replicate assays were performed at each concentration. Mean +1 SD indicated. For any individual assay, a treatment was considered deterrent if the number of pellets eaten was less than or equal to 6 ( $\mathrm{p}<0.043$, Fisher exact test, 1-tailed) as indicated by the dashed line

ageliferin (8) $\left(0.09 \mathrm{mg} \mathrm{ml}^{-1}\right)$, ageliferin (6) $(0.07 \mathrm{mg}$ $\left.\mathrm{ml}^{-1}\right)$, bromosceptrin $(4)\left(0.05 \mathrm{mg} \mathrm{ml}^{-1}\right)$.

The purified bromopyrrole alkaloids from Agelas wiedenmayeri were subjected to aquarium assays separately and in combination (Fig. 5). At natural concentrations of 1.6 and $0.7 \mathrm{mg} \mathrm{ml}^{-1}, 4,5$-dibromopyrrole-2carboxylic acid (1) and oroidin (2) were deterrent when assayed separately, but bromoageliferin (7) was not deterrent at $0.24 \mathrm{mg} \mathrm{ml}^{-1}$ when assayed separately. The activity of all 3 metabolites combined was about the same as that for 4,5-dibromopyrrole-2-carboxylic acid (1) alone (Fig. 5).

Initial results of the structure-activity relationship of pyrrole-2-carboxylic acid derivatives were obtained. Activity of the molecule was enhanced with addition of bromine to the pyrrole group (compare 9, 10, 11, 1; Fig. 6). Compound activity was not affected by the exchange of the heteroatom from $\mathrm{N}$ to $\mathrm{O}$ or $\mathrm{S}$ (compare $\mathbf{9}, \mathbf{1 5}, \mathbf{1 6}$, 11, 17; Fig. 6), whereas none of the proline derivates were active at $100 \mathrm{mg} \mathrm{ml}^{-1}(\mathbf{9}$ compared to 19, 20; Fig. 6). Modification of the carboxy group did not lead to an unambiguous change in activity (9 compared to 12-14).

\section{DISCUSSION}

Sponges of the genus Agelas appear to protect themselves from fish predators using chemical defenses,

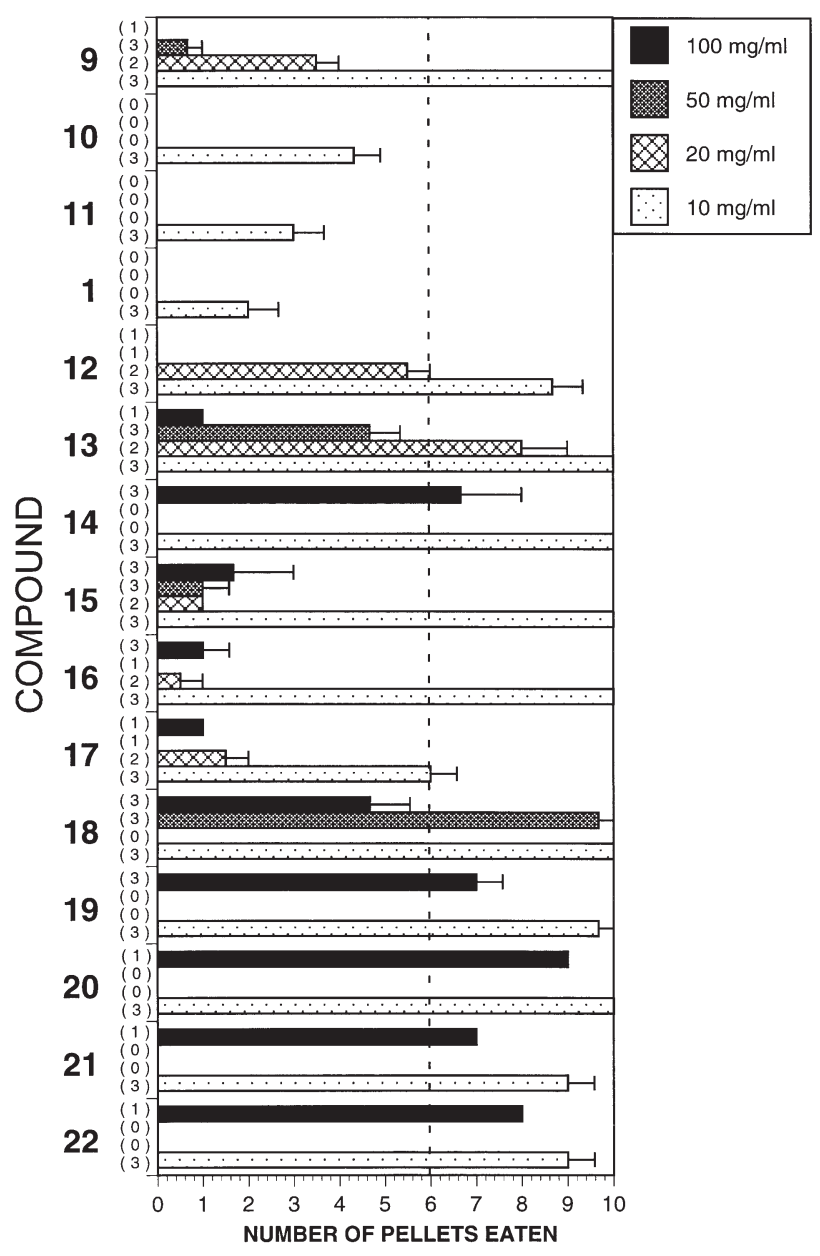

Fig. 6. Aquarium assay results of feeding by Thalassoma bifasciatum on pellets treated with 1 purified compound from Agelas wiedenmayeri, and synthetic and purchased compounds used to assess structure-activity relationships (see Fig. 1) at concentrations of $10,20,50$, and $100 \mathrm{mg} \mathrm{ml}^{-1}$. All control pellets were eaten in all assays. The number of replicate assays is shown in parentheses to the right of each compound number. Mean + SE indicated. For any individual assay, a treatment was considered deterrent if the number of pellets eaten was less than or equal to 6 ( $p<0.043$, Fisher exact test, 1-tailed) as indicated by the dashed line

because structural defenses alone, in the form of spongin fibers and glass spicules, were ineffective feeding deterrents in aquarium and field assays (Chanas \& Pawlik 1995, 1996). The present study expands on a previous report (Chanas et al. 1996) that identified 4,5dibromopyrrole-2-carboxylic acid (1) and oroidin (2) as the defensive metabolites of A. clathrodes to demonstrate that the same metabolites protect $A$. wiedenmayeri, and that related, dimeric metabolites protect A. conifera.

Similarities in the secondary metabolites found in Agelas clathrodes and A. wiedenmayeri versus A. conifera parallel differences in the silicious spicules found 
in the tissues of the 3 species of sponges (Wiedenmayer 1977, Assmann et al. 1999). Although shape, size, and color of all 3 Agelas species are distinctly different, A. clathrodes and A. wiedenmayeri appear more closely related based on similar spicule sizes: 95 to $140 \times 4$ to $8 \mu \mathrm{m}$, with 9 to 13 whorls of spines for A. wiedenmayeri, and 70 to $155 \times 2.5$ to $7.5 \mu \mathrm{m}$ with 7 to 15 whorls of spines for A. clathrodes. For A. Conifera, spicules are clearly longer and thicker (117 to $192 \times 10$ to $16 \mu \mathrm{m})$ and the whorls are more numerous (11 to 19) than in $A$. clathrodes and A. wiedenmayeri.

Although the same metabolites are found in Agelas wiedenmayeri as in A. clathrodes, the relative concentrations are different. Mean oroidin (2) concentrations in $A$. clathrodes were $1.4 \mathrm{mg} \mathrm{ml}^{-1}$, with concentrations of 4,5-dibromopyrrole-2-carboxylic acid (1) that were estimated at $25 \%$ of those of oroidin (2) (Chanas et al. 1996). In contrast, for 4 of 5 samples of $A$. wiedenmayeri, concentrations of 4,5-dibromopyrrole-2-carboxylic acid (1) exceeded those of oroidin (2), and in the remaining sample, the concentrations were about the same (Table 1). The combined mean concentration of both of these metabolites was greater in samples of $A$. wiedenmayeri $\left(\sim 2.82 \mathrm{mg} \mathrm{ml}^{-1}\right)$ than in A. clathrodes $\left(\sim 1.75 \mathrm{mg} \mathrm{ml}^{-1}\right)$. Considering that 4,5-dibromopyrrole2-carboxylic acid (1) and oroidin (2) were deterrent at 1.6 and $0.7 \mathrm{mg} \mathrm{ml}^{-1}$, respectively (Fig. 5), the former compound was present in sufficient quantity in all samples of $A$. wiedenmayeri to inhibit feeding (Table 1); in combination with the latter compound, the effect is most likely additive, as a synergistic response to the mixture was not evident (Fig. 5). There was no evidence of synergy when combinations of brominated pyrrole alkaloids were tested in a previous study (Lindel et al. 2000). Although bromoageliferin (7) was present in samples of $A$. wiedenmayeri, its concentration was very low $(<10 \%$ of the bromopyrrole alkaloid fraction), and its impact of the feeding deterrent effect of the mixture was negligible (Fig. 5).

Unlike Agelas clathrodes and A. wiedenmayeri, A. conifera is chemically defended by dimeric bromopyrrole alkaloids (Fig. 1). This suite of compounds (3-8) appear to be more potent feeding deterrents than either 4,5-dibromopyrrole-2-carboxylic acid (1) or oroidin (2) (compare Figs. 3, 5 \& 6), perhaps because each dimeric molecule contains 2 brominated pyrrole groups rather than just one. With more potent chemical defenses on a per molecule basis, it might be expected that $A$. conifera would have lower concentrations of these compounds than A. clathrodes or A. wiedenmayeri; on the contrary, sceptrin (3) concentrations alone in A. conifera are about twice those of 4,5-dibromopyrrole-2carboxylic acid (1) and oroidin (2) in A. wiedenmayeri (Tables 1 \& 2). Moreover, there were higher levels of sceptrin (3) in samples of $A$. conifera taken from the southern Bahamas than those taken from sites around the 'Tongue of the Ocean', a deep body of water that is mostly enclosed by land and the Great Bahama Bank in the middle Bahamas. Fluctuations in sceptrin (3) concentrations were not compensated by changes in the concentrations of the other dimeric compounds identified from this species to yield equivalent total concentrations; HPLC analysis revealed that the proportion of the minor compounds fluctuated proportionally to sceptrin (3). It is unclear whether differences in sceptrin (3) concentration reflect differences in predation pressure, or perhaps differences in water quality or flow associated with geography.

The first systematic investigation of the structureactivity relationship between marine natural products and fish feeding deterrents was performed for brominated pyrrole alkaloids from Agelas spp. (Lindel et al. 2000). The present study expands on the importance of the pyrrole moiety for fish feeding inhibition by demonstrating the importance of the unsaturated 5-membered ring (pyrrole). Substitution of the heteroatom in the ring did not greatly affect compound activity, but the loss of unsaturation resulted in the loss of activity (Fig. 6). The importance of bromination was clearly demonstrated, as compound palatability increased with each loss of a bromine atom from the pyrrole (Fig. 6). Dimerization of oroidin (2) does not appear to alter compound activity; in fact, the brominated pyrrole groups appear to retain their independent activity to increase the potency of the dimerized compounds (3-8). Comparing the relative feeding deterrent activities of the major naturally occurring metabolites at $1 \mathrm{mg} \mathrm{ml}^{-1} \mathrm{con}-$ centrations, but expressed as mol ml $\mathrm{m}^{-1}$, a hierarchy of activity can be determined: bromoageliferin $(\mathbf{7})=$ sceptrin (3) > dibromoageliferin (8) = dibromosceptrin (5) > oroidin (2) > 4,5-dibromopyrrole-2-carboxylic acid (1). Although dibromoageliferin (8), dibromosceptrin (5) and bromoageliferin (7) are potent feeding deterrents, they are present in only trace amounts in sponge tissue, at concentrations lower than would be required to deter feeding. Sceptrin (3) is the only dimeric compound present in sponge tissue at concentrations sufficient to defend $A$. conifera. The minor dimeric compounds may represent metabolic byproducts.

These results extend our understanding of the chemical basis of the ecological functions of bromopyrrole alkaloids in marine sponges and confirm the importance of the presence and arrangement of functional groups to compound activity.

Acknowledgements. Financial support for this research was provided by grants from the Deutsche Forschungsgemeinschaft (Ko 1314/3-1 to 3-4) and from the US National Science Foundation (OCE-9711255 to J.R.P.). The latter included University-National Oceanographic Laboratory System support for the use of the RVs 'Edwin Link' and 'Seward Johnson'. We 
are grateful to Rob W. M. van Soest (Instituut voor Biodiversiteit en Ecosysteemdynamica, Zoölogisch Museum, Universiteit van Amsterdam, The Netherlands) for his expert help with sponge identification. Greg McFall, Dan Pisut and Tim Henkel at the University of North Carolina at Wilmington assisted with feeding assays. We thank the captain and the crew of the RV 'Edwin Link', the RV 'Seward Johnson', and the staff of the National Undersea Research Center at Key Largo, Florida, USA, for their cooperation. We thank the government of the Bahamas for permission to perform research in their territorial waters.

\section{LITERATURE CITED}

Anderson HJ, Lee SF (1965) Pyrrole chemistry. IV. The preparation and some reactions of brominated pyrrole derivatives. Can J Chem 43:409-414

Assmann M, Lichte E, van Soest RWM, Köck M (1999) New bromopyrrole alkaloid from the marine sponge Agelas wiedenmayeri. Org Lett 1:455-457

Bailey DM, Johnson RE, Albertson NF (1971) Ethyl pyrrole-2carboxylate. Org Syn 51:100-102

Braekman JC, Daloze D, Stoller C, van Soest RWM (1992) Chemotaxonomy of Agelas (Porifera: Demospongiae). Biochem Syst Ecol 20:417-431

Chanas B, Pawlik JR (1995) Defenses of Caribbean sponges against predatory reef fish. II. Spicules, tissue toughness, and nutritional quality. Mar Ecol Prog Ser 127:195-211

Chanas B, Pawlik JR (1996) Does the skeleton of a sponge provide a defense against predatory reef fish? Oecologia 107:225-231

Chanas B, Pawlik JR, Lindel T, Fenical W (1996) Chemical defense of the Caribbean sponge Agelas clathrodes

Editorial responsibility: Otto Kinne (Editor), Oldendorf/Luhe, Germany
(Schmidt). J Exp Mar Biol Ecol 208:185-196

Forenza S, Minale L, Riccio R, Fattorusso E (1971) New bromo-pyrrole derivatives from the sponge Agelas oroides. J Chem Soc Chem Comm 1129-1130

Garcia EE, Benjamin LE, Fryer RI (1973) Reinvestigation into the structure of oroidin, a bromopyrrole derivative from marine sponge. J Chem Soc Chem Comm 78-79

Keifer PA, Schwartz RE, Koker MES, Hughes RG Jr, Rittschof D, Rinehart KL (1991) Bioactive bromopyrrole metabolites from the Caribbean sponge Agelas conifera. J Org Chem 56:2965-2975, errata 5736, 6728

Kobayashi J, Tsuda M, Murayama T, Nakamura H, Ohizumi Y, Ishibashi M, Iwamura M, Ohta T, Nozoe S (1990) Ageliferins, potent actomyosin ATPase activator from the Okinawan marine sponge Agelas sp. Tetrahedron 46: 5579-5586

Lindel T, Hoffmann H, Hochgürtel M, Pawlik JR (2000) Structure-activity relationship of the inhibition of fish feeding by sponge-derived and synthetic pyrrole-imidazole alkaloids. J Chem Ecol 26:1477-1496

Pawlik JR, Burch MT, Fenical W (1987) Patterns of chemical defense among Caribbean gorgonian corals: a preliminary survey. J Exp Mar Biol Ecol 108:55-66

Pawlik JR, Chanas B, Toonen RJ, Fenical W (1995) Defenses of Caribbean sponges against predatory reef fish. I. Chemical deterrency. Mar Ecol Prog Ser 127:183-194

Walker RP, Faulkner DJ, van Engen D, Clardy J (1981) Sceptrin, an antimicrobial agent from the sponge Agelas sceptrum. J Am Chem Soc 103:6772-6773

Wiedenmayer F (1977) Shallow-water sponges of the western Bahamas. Experientia Suppl 28. Birkhäuser Verlag, Stuttgart

Zar JH (1999) Biostatistical analysis, 4th edn. Prentice-Hall, Upper Saddle River, NJ

Submitted: March 12, 2000; Accepted: August 15, 2000 Proofs received from author(s): September 21, 2000 